\author{
Joanna Cukras-Stelągowska
}

\title{
Kulturowe wzbogacenie, zagubienie czy wykluczenie? Konsekwencje wychowania w żydowskiej rodzinie mieszanej w kontekście europejskich raportów
}

Streszczenie: Przedmiotem podjętych rozważań uczyniłam kwestię kształtowania tożsamości dzieci wychowanych w rodzinach mieszanych. W świetle trzech europejskich raportów chciałabym odpowiedzieć na pytanie, czy jest to kulturowe wzbogacenie, zagubienie czy może wykluczenie dla jednostki? Raporty niemiecki, holenderki i francuski ukazują konsekwencje dla dojrzewania w obliczu poważnych wyzwań identyfikacyjnych młodych osób pochodzenia żydowskiego. Staram się dokonać porównań rezultatów badawczych trzech zespołów, poszukując cech wspólnych dla tych krajów, a także starając się wskazać specyfikę badanych obszarów kulturowych.

Słowa kluczowe: żydowskie rodziny mieszane, wychowanie żydowskie, identyfikacja

Inspiracją do podjęcia tematyki wychowania w rodzinie dwukulturowej była lektura trzech europejskich raportów, które powstały na zlecenie organizacji JDC International Centre for Community Development (JDC ICCD) w 2014 roku. Społeczność żydowska w specyficzny sposób rozumie „małżeństwo mieszane", problemem nie są to bowiem tylko związki binacjonalne czy dwureligijne. Ważną kwestią jest również kryterium płci. Jeżeli żydowska kobieta wychodzi za mąż za nie-Żyda, to dzieci z tego związku uznane będą za Żydów (kryterium halachiczne). Jeżeli ojcem jest Żyd, a matka nie jest Żydówką, to ich dzieci nie są uznane za Żydów (wyjątek stanowi judaizm reformowany) i muszą przejść przez proces konwersji, jeżeli chcą w pełni uczestniczyć w życiu żydowskiej wspólnoty (w życiu synagogi i modlitwach, obrzędach religijnych w cyklu życia). Mimo to, związki mieszane w kulturze judaistycznej są obecnie bardzo rozpowszechnione, zwłaszcza w Stanach Zjednoczonych. Stamtąd także pochodzą najgłośniejsze słowa krytyki liderów społeczności żydowskiej. Od lat 60. XX wieku procesy te interesują również przedstawicieli nauk społecznych, 
literatura amerykańska z tego zakresu jest obszerna (Alba 2006; Barack i Fisman 1994; Berman 1968; Brodbar-Nemzer 2010; Goldscheider 2004; Gordon 2014; Green 2011; Spickard 1989; Larkin 2014; Thompson 2014). Przy czym należy podkreślić, że ujęcie tego problemu przeszło pewną znaczącą ewolucję. Rodziny mieszane w drugiej połowie XX wieku prezentowane były najczęściej w dyskursie dysfunkcji społecznych i nieuniknionej asymilacji, jednakże u progu nowego millenium zaobserwować można, że ta nieoficjalna „norma” sprawnie wkomponowuje się w model społeczeństwa wielokulturowego. Małżeństwa mieszane w USA stanowią obecnie niemal połowę związków zawieranych w judaizmie reformowanym, jedną piątą w judaizmie konserwatywnym i pośród Żydów niereligijnych, najrzadziej zdarzają się wśród Żydów ortodoksyjnych (12\% w 2013 r.) (Heilman, 2013). Interesującym i symptomatycznym jest, że powstają nawet poradniki dla takich rodzin (Petsonk i Remsen, 2012). Keren R. McGinity (2012) dokonawszy przeglądu literatury przedmiotu również stoi na stanowisku, iż w ciągu ostatnich dwóch dekadach nastąpiła wyraźna zmiana, przejście od ujęcia rodzin mieszanych $\mathrm{w}$ modelu asymilacyjnym do modelu transformacyjnego bądź balansowanie pomiędzy nimi. USA to bez wątpienia doskonały przykład wyraźnego rozdźwięku pomiędzy głosem liderów żydowskich i rabinów a praktyką społeczną. To także swoiste obserwatorium stopniowego łagodzenia stanowiska instytucjonalnego w odpowiedzi na zmiany społeczne.

Fenomen małżeństw mieszanych wśród Żydów ma kilka źródeł. Po pierwsze: wiąże się z wysokim stopniem integracji ze społeczeństwem amerykańskim na polu zawodowym, edukacyjnym, politycznym czy kulturowym oraz znacznym stopniem akceptacji tego typu małżeństw w amerykańskim mainstreamie (Barack Fisman, 1994, s. 25). Po drugie: łączy się z nieuniknioną płynnością granic etnicznych, jako że w nowym millenium kontakty międzykulturowe stały się codziennością. Te interakcje przesunęły się także w kierunku relacji partnerskich z nie-Żydami (Goldscheider, 2004, s. 22; Barack Fisman, 1994, s. 25). Zmniejsza się poziom nietolerancji wobec małżeństw mieszanych, nie zmusza się partnera do zmiany religii, dzięki czemu dwa wzory kulturowe w jednej rodzinie stają się czymś zwyczajnym, a w otwartym typie społeczeństwa wręcz nieuniknionym (Barack Fisman, 1994, s. 5). Po trzecie: ma swoje źródła w procesach sekularyzacji, zeświecczenia praktyk życia rodzinnego bądź przesunięcia religii do sfery prywatnej, intymnej (Brodbar-Nemzer, 1988, s. 66). Dla opisu tych trendów we współczesnej rodzinie żydowskiej socjologia amerykańska sięga do terminu „rodzina posthalachiczna” (Teutsch, 1992, s. 37).

Pomimo powszechności tego typy małżeństw, prężne rozwijającego się judaizmu reformowanego (zdecydowanie bardziej otwartego na pary dwureligijne), 
krytyka ze strony liderów ortodoksyjnych oraz badaczy (często wywodzących ze społeczności żydowskiej) nie ustaje. Głównym argumentem przemawiającym za wspieraniem rodzin endogamicznych (obok oczywiście religijnych) jest konstatacja, że związki mieszane są mniej skłonne do wychowania swoich dzieci w tradycji żydowskiej, czy wręcz obawy, że następne pokolenie porzuci swoją żydowską tożsamości (Dershowitz 1997). W konsekwencji społeczności żydowskiej grozić może erozja etniczna. Istotnie, amerykańskie badania sondażowe $\mathrm{z}$ ostatnich kilku lat potwierdzają słabszą identyfikację dzieci z rodzin mieszanych z żydostwem w ich dorosłym życiu (m.in. Cohen, Ukeles i Miller, 2011).

Z kolei wśród argumentów przemawiających za większą akceptacją i zrozumieniem, pojawiają się stwierdzenia mówiące o tym, że małżeństwa mieszane to pozytywny przejaw społecznej integracji. Ponadto, związki te mogą wzbogacają osobowość jednostki poprzez codzienne doświadczenie i uczenie się pluralizmu (Linzer, 1995, s. 6). Ciekawą przesłanką jest także przekonane o rewitalizacji społeczności dzięki identyfikacji nie-żydowskiego partnera z żydostwem, nowymi (choć niepełnym) jej członkom, którzy w przyszłości mogą zdecydować się na konwersję, co z kolei będzie skutkować zwiększeniem uczestnictwa w życiu synagogi i innych instytucjach żydowskich (Barack Fisman, 2004, s. 7; Goldscheider, 2004, s. 22). Rodziny dwukulturowe mogą zatem przyczynić się do zwiększenia populacji żydowskiej, także przez to, że urodzi się więcej dzieci w dwóch związkach mieszanych niż w jednej rodzinie żydowskiej (Sasson, Aronson i Chertok, 2015). Optymistycznym faktem może być również, że w świetle niektórych badań niemal połowa dzieci z rodzin mieszanych deklaruje się jako Żydzi (Goldscheider, 2004, s. 24).

Amerykańskie wzory kulturowe zazwyczaj się niezwykle interesujące dla Starego Kontynentu, szybko znajdują i tutaj podatny grunt. Nie dziwią zatem obawy liderów religijnych i społecznych o to czy sytuacja rodzin żydowskich w Europie będzie rozwijała się w podobnym kierunku. Powstałe w 2014 roku raporty to pierwsze kompleksowe badania nad tożsamością dzieci z rodzin mieszanych w społecznościach żydowskich Europy Zachodniej. Wypełniają one istotną lukę badawczą, choć nie wyczerpują w pełni kontekstów europejskich. Interesującym jest także chociażby raport brytyjski Jews in couples: Marriage, intermarriage, cohabitation and divorce in Britain, Institute for Jewish Policy Research Report (Graham, 2016). Z uwagi na inną instytucję organizującą badania oraz ich ilościowy charakter, projekt ten nie został włączony do poniższych analiz.

W niniejszym artykule postanowiłam bliżej przyjrzeć się skutkom wychowania w rodzinie mieszanej, dokonując porównania rezultatów badaw- 
czych trzech zespołów, poszukując przy tym cech wspólnych dla omawianych krajów, a także starając się wskazać na specyfikę badanych obszarów kulturowych. Pokrótce wyniki tych badań charakteryzowałam już przy okazji refleksji nad fenomenem małżeństw mieszanych w judaizmie (Cukras-Stelągowska, 2016).

\section{Wychowanie w rodzinie mieszanej - raporty europejskie}

Wszystkie omawiane raporty powstały na zlecenie organizacji JDC International Centre for Community Development (JDC ICCD), centrum badawczego powstałego w 2005 roku przy Uniwersytecie Oksfordzkim. Ten uznany Ośrodek prowadzi liczne badania skoncentrowane na analizach procesów transformacji społeczności żydowskiej w Europie. 2014 roku trzy zespoły naukowców przeprowadziły pierwsze, wszechstronne, badania nad zjawiskiem małżeństw mieszanych w trzech krajach: Francji, Niemczech i Holandii.

Koordynatorem badań francuskich była Julia David, doktor nauk politycznych, wykładowca Uniwersytetu Londyńskiego, doświadczony badacz i uczestnik staży podoktorskich między innymi na Uniwersytecie Oksfordzkim i Nowojorskim. Raport ma charakter jakościowy, objął swym zasięgiem społeczność żydowską zamieszkującą paryską metropolię. Grupę rozmówców stanowiło 50 osób pomiędzy 20 a 40 rokiem życia, z rodzin mieszanych, wywodzących się zarówno z grupy aszkenazyjskiej i sefaradyjskiej, a także o różnych poziomach afiliacji religijnej. Dzięki wywiadom pogłębionym poznajemy subiektywne „światy przeżywane” młodych ludzi, wychowanych w dwóch kulturach. Ich unikatowe rozwiązania identyfikacyjne są płynne i zmienne w cyklu życia, przy tym żaden z respondentów nie odrzuca całkowicie swojej „cząstki żydowskości". Niektórzy jednak dość radykalnie rozwiązują dylematy poprzez wybór tzw. „trzeciej tożsamości”, czy „tożsamości neutralnej” lub rezygnują z identyfikacji religijnej; jeszcze inni konstruuja „podwójną tożsamość”, szukając harmonii i unikając wewnętrznych napięć; trzecia droga - to apelowanie do symbolicznych zasobów, które posiadają obie tradycje i wytworzenie „nowej identyfikacji" spośród wyselekcjonowanych elementów; kolejna - prowadzi do przekonania o niemożliwości samo-definiowania w codziennych kontekstach; jeszcze inna - do definiowania siebie w kategoriach quasi-matematycznych (bycie „pół-Żydem” „pół na pół” etc.); ostatnie możliwe rozwiązanie to ciągłe konfrontowanie ze środowiskiem żydowskim i nie-żydowskim swojej identyfikacji (Dawid, 2014, s. 11-12). 
Zdaniem Autorki, trwała i stabilna identyfikacja ze światem żydowskim w dorosłym życiu uzależniona jest przede wszystkim od wczesnej edukacji i uczestnictwa w życiu instytucjonalnym oraz aktywności w gminie żydowskiej jak najmłodszych dzieci wychowywanych w rodzinach mieszanych (2014, s. 16). Drugim ważnym czynnikiem są postawy rodziców i dziadków. Nie-żydowscy członkowie rodziny często zachęcają i wspierają młodych ludzi w ich poszukiwaniach tożsamościowych. Występują jednak sytuacje odrzucenia w rodzinie, wrogość, uprzedzenia, a nawet antysemityzm, który może skutkować odrzuceniem żydowskiej tożsamości, ale także odwrotnie - jej większą afirmacją (tamże, s. 17-19). Ze strony rodziców żydowskich ujawniła się niewystarczającą transmisję dziedzictwa kulturowego, brak religijnej i kulturowej wiedzy starszego pokolenia. Część badanych wskazuje jednak, że nawet minimalistyczne praktyki religijne w domu rodzinnym miały dla nich znaczenie w późniejszym poszukiwaniu żydowskiej identyfikacji, w szczególności istotny był przekaz tradycji od dziadków. Niekiedy młodzież obserwowała powroty do żydostwa swoich rodziców (np. na pogrzebie dziadków ojciec po raz pierwszy założył jarmułkę, co spowodowało uruchomienie procesu własnych poszukiwań). Rozpoczynając swoje głębsze zaangażowanie młodzi żydzi często nie posiadają jednak dużego kapitału kulturowego, a jedynie emocjonalne poczucie więzi ze społecznością i wspólnota pamięci o Holokauście (szczególnie jeśli ofiarami byli starsi członkowie ich rodzin) (Tamże, s. 14-16).

Jak udowodniły badania, fundamentalne znaczenie dla dalszego rozwoju tożsamości żydowskiej ma posiadanie halachicznego pochodzenia. Osoby posiadający żydowską matkę mają łatwiejszą drogę dla ukształtowania pozytywnej identyfikacji, chociaż często również czują się w pewien sposób "mieszani kulturowo”, gdyż byli wychowywani w dwóch kulturach jednocześnie, a ich ojcowie nie są Żydami. Z kolei respondenci posiadający żydowskiego ojca pomimo, że często są bardziej zaangażowani, napotykają na kryteria matrylinearne, które uniemożliwiają im głębsze zbudowanie tożsamości religijnej. Zdarza się jednak, że osoby te ukierunkowują się na rozwój religijny, pomimo niemożności wypełnienia wszystkich wymogów judaizmu, nieliczni zaś decydują się na konwersję, choć próba konwersji ortodoksyjnej opisywana jest zawsze jako trudne doświadczenie) (tamże, s. 15). Poczucie odrzucenia ze strony społeczności żydowskiej wywołuje ambiwalencję tożsamości, nierzadko zahamowanie jej rozwoju, jednak czasami upokorzenia jakich doznają młodzi ludzie są mniej ważne od potrzeby afiliacji żydowskiej (tamże, s. 19). 
Osoby wychowane w rodzinie mieszanej sami są najczęściej w związkach z nie-Żydami. Swoistym jest, że niektórzy woleliby nie wiązać się z Żydami o bardziej ugruntowanej tożsamości, bo to oznaczałoby dla nich ciągłą konfrontację z poczuciem przynależności narodowej/religijnej. Wolą zatem wchodzić w związki mieszane z partnerami, którzy także na przykład są tylko w połowie Żydami. Równocześnie osoby te są świadome, że ich dzieci w jeszcze mniejszym stopniu będą Żydami. Z kolei inni respondenci decydują się na związki monokulturowe, po to, aby ich dzieci uniknęły tych trudnych doświadczeń, przez jakie oni sami przechodzili (tamże, s. 20).

Raport zwraca uwagę na dysonans między pragnieniem „spersonalizowania przynależności grupowej" u dzieci z rodzin mieszanych a zachowanie historycznej kontynuacji judaizmu, do czego zobowiązane są żydowskie instytucje (tamże, s. 11). Z trudem tworzona indywidualna tożsamość może łatwo zostać zniszczona przez instytucjonalne żądania legitymizacji pochodzenia. Rozwiązaniem może być konwersja bądź poszukiwanie akceptacji w bardziej otwartych ruchach reformowanych albo konserwatywnych. Dużym problemem są jednak już zainwestowane koszty społeczne, gdyż młodzi ludzi są często bardzo zaangażowani w życie wspólnoty żydowskiej, podejmują wielkie starania o włączenie do społeczności (tamże, s. 13). Badania francuskie pokazuje skutki wykluczenia instytucjonalnego z kultury mniejszościowej na poziomie mikrospołecznym. Niewiele dowiadujemy się o charakterze relacji i identyfikacji ze społecznością dominującą. Respondenci przyznają, ze w dzieciństwie doświadczyli postaw antysemickich, także ze strony nie-żydowskiej części swojej rodziny. Zdają się być raczej zagubieni w swojej „dwukulturowości”. Trudno wnioskować czy rzeczywiście nie odczuwają pozytywnych konsekwencji wychowania w obu kulturach, gdyż w badaniach zabrakło bezpośrednich pytań o potencjalnie wzbogacające skutki życia w rodzinie mieszanej.

Autorami raportu holenderskiego są Barbara Tanenbaum (związana z instytucją JMW-Jewish Social Services w Amsterdamie) i Riki Kooyman (niezależny badacz). W ponad 40 stronnicowym materiale znajdziemy szereg informacji na temat niezwykle zróżnicowanych, zindywidualizowanych i zmiennych form żydowskiej identyfikacji wśród respondentów (50 osób $\mathrm{w}$ wieku od 20 do 40 lat z rodzin mieszanych, również $8 \mathrm{z}$ rodzin izraelskich, ponieważ Izraelczycy stanowią w Holandii 20\% populacji żydowskiej) (Tanenbaum i Kooyman,2014, s. 12). Badania skrupulatnie wyznaczają główne areały więzi społecznych, religijnych, wskazują na silniejsze i nieco słabsze (a czasami krytyczne) więzi z państwem Izrael (tamże, s. 22-25). Autorzy wy- 
odrębnili trzy główne wzory identyfikacji: 1. „Bycie Żydem i poczucie bycia nim w codziennym życiu" (głównie osoby posiadające żydowską matkę); 2. „Poczucie bycia Żydem, ale..." (poczucie, że nie jest się w pełni Żydem, są to osoby posiadające żydowskiego ojca); 3. „Brak poczucia tożsamości żydowskiej, przy zachowaniu związków z judaizmem i pamięci rodzinnej", jest to mała grupa osób z pochodzeniem niehalachicznym, mające dalsze korzenie po dziadkach (tamże, s. 13-14).

Badana grupa to głównie osoby niereligijne, niepraktykujące, ale odczuwające związki z tradycją, również religijną. Często na przykład obchodzącą główne święta żydowskie ( $w$ tej podgrupie są przeważnie osoby z halachicznym pochodzeniem) (tamże, s. 20-21). Raport wskazuje, iż dla osób wychowanych w rodzinach mieszanych zazwyczaj jedyną formą identyfikacji jest pamięć o Szoah, związki emocjonalne z Izraelem i świadomość istnienia antysemityzmu, który jako negatywny bodziec kieruje ku budowaniu tożsamości żydowskiej identyfikacyjny (nawet jeśli nie jest przez nich osobiście doświadczany) (tamże, s. 29). Poczucie bliskości z kulturą żydowską jednak nie wiąże się z zaangażowaniem w żydowskie praktyki kulturowe ani życie społeczne. Jedynie co piąty badany deklaruje aktywny udział w życiu synagogi bądź innej żydowskiej organizacji, oraz że posiada dużą wiedzę o judaizmie, obchodzi żydowskie święta, stosuje się do zasad koszeru, dobiera przyjaciół bądź partnera w kręgach żydowskich etc. (tamże, s. 14-15).

Drugim, rozbudowanym w tych badaniach, wątkiem są relacje ze społecznością żydowską. Poznajemy często negatywne opinie na temat wspólnoty żydowskiej w Holandii, jak również dowiadujemy się o nieprzychylnych postawach wobec osób nieposiadających halachicznego pochodzenia (a nawet generalnie nowych członków) (tamże, s. 40). Badana grupa nie ma charakteru inkluzywnego, a żydowskie więzi kulturowe są zindywidualizowane, obejmują raczej prywatną przestrzeń (np. jedzenie typowych dań żydowskiej kuchni, udział w festiwalach i przeglądach filmów o tematyce żydowskiej, słuchanie żydowskiej muzyki etc.) (tamże, s. 19). Połowa badanych żyje w związkach, ale zaledwie troje z nich na żydowskiego partnera/męża. Ich zdaniem umacnia to wiarę, szczególnie poprzez wspólne celebrowanie świąt. Natomiast jak przekonują pozostali respondenci, nie-żydowscy partnerzy mają neutralny wpływ na rozwój tożsamości żydowskiej, którą zresztą badani uważają za sprawę bardzo intymną, prywatną (tamże, s. 34).

Badania dużo mówią o samym charakterze wychowania w rodzinie dwukulturowej, o wpływie wychowawczym matki bądź ojca, a także roli żydowskich dziadków. Dziadkowie, którzy zginęli albo ocaleli z Holokaustu mieli 
ogromny wpływ na formowanie się tożsamości żydowskiej młodzieży reprezentującej tzw. „trzecie pokolenie”. Zrodziło to w młodych ludziach poczucie odpowiedzialności za przyszłość wspólnoty (tamże, s. 27-28). W społeczności holenderskiej nie-żydowski rodzin przeważnie akceptował i wspierał obecność żydowskich elementów w wychowaniu (tamże, s. 31). Ponownie, ogromne znaczenie ma typ rodziny mieszanej. Dzieci wychowanie w rodzinie, w której matka jest Żydówka, w dorosłym życiu są bardzo związane z judaizmem. Mają pełną swobodę wyboru instytucji i skali swojego zaangażowania. Co ciekawe, osoby te nie uznają, że były wychowane w „rodzinie mieszanej" (inaczej niż w raporcie francuskim). Dorastanie w rodzinie, w której żydowskie korzenie ma tylko ojciec, skutkuje bardziej skomplikowanymi rozwiązaniami identyfikacyjnymi. Wymagania instytucjonalno-religijne determinują los jednostki, a nie jej subiektywne wybory. W tej grupie, 12 osób deklaruje, że w rodzinnym domu celebrowano pewne elementy kultury żydowskiej, często razem z dziadkami. Rodzice nie dysponowali dużą wiedzą o kulturze żydowskiej, nastąpiło przerwanie transmisji dziedzictwa międzygeneracyjnego (tamże, s. 31-32). Jednakże największą grupę spośród osób z korzeniami patrylinearnymi (lub bardziej odległym pochodzeniem) stanowią respondenci, którzy nie mieli żadnego wychowania żydowskiego. Dla nich jedyną agendą socjalizacji byli dziadkowie. Jedynie nieliczni, mimo braku żydowskiego domu, zainteresowali się i zaangażowali w judaizm na późniejszym etapie swojego życia (tamże, s. 31-32). Utrzymują do dzisiaj związki z żydowskim życiem, ale doświadczyli osobiście odrzucenia, wykluczenia ze społeczności. Niekiedy to żydowscy ojcowie badanych zniechęcali do głębszego zaangażowania (np. do wyjazdów do Izraela), bo byli przekonani, że dzieci nie zostaną w pełni akceptowane przez społeczność żydowską. Co więcej, niektóre osoby dokonują „samo-wykluczenia”, internalizując zasady matrylineażu (tamże, s. 36-38).

Za sprawą raportu poznajemy również aspiracje wychowawcze: większość respondentów posiadających dzieci, nie wychowuje ich w duchu judaizmu, niektórzy tłumaczą to niehalachicznym pochodzeniem matki, inni chcą pozostawić wybór dziecku, większość chce jednak, aby dzieci były świadome swego pochodzenia (tamże, s. 35).

Trzeci raport autorstwa antropolog kultury Julii Bernstein objął badaniem 45 osób z pochodzeniem żydowskim mieszkających w Niemczech (26 respondentów posiadało żydowską matkę, 19 - żydowskiego ojca). W tej grupie znalazło się aż 21 osób, które wyemigrowały z byłego Związku Radzieckiego (bowiem w społeczności żydowskiej w Niemczech tak grupa stanowi 
90-95\%) (Bernstein, 2014, s. 10). Doświadczenia migracyjne stanowiły w tym przypadku drugi, niezwykle istotny i trudny aspekt identyfikacyjny. Z kolei dla osób urodzonych w Niemczech takim dodatkowym obciążeniem była bolesna historia niemiecko-żydowska (także w ich rodzinach). Raport wskazuje, że egzogamia nie zawsze jest katalizatorem procesów asymilacji i nie musi prowadzić do społecznych, kulturowych czy religijnych konfliktów. Większość badanych konstruuje bardzo indywidualne, selektywne i sytuacyjne wzory identyfikacyjne, pewien rodzaj elastycznych „kalejdoskopowych identyfikacji” (czasami są to „hybrydy tożsamościowe”), unikając jednoznacznych definicji „albo-albo” (tamże, s. 7). W tym badaniu akcent położono na różne formy autoidentyfikacji - nie tylko etnicznej i religijnej, ale także zawodowej, hobbystycznej, etc. Co sprawia, że otrzymujemy pełniejszy obraz, a identyfikacja „bycie Żydem” okazuje się być ważnym, ale nie jedynym elementem tożsamości jednostki (tamże, s. 16).

Niemieccy Żydzi, podobnie jak przedstawiciele społeczności żydowskiej we Francji i Holandii, nie są bardzo religijni. Prezentują indywidualne i selektywne realizacje praktyk religijnych (np. odwiedzanie synagogi w najważniejsze święta żydowskie, czasowe stosowanie się do kaszrutu, nieregularne obchodzenie szabasu). Raport brytyjski, przygotowany na zlecenie Institute for Jewish Policy (JPR), porównując realizację praktyk religijnych w rodzinach endogamicznych i egzogamicznych również wskazuje na istotne różnice w tej kwestii (Graham, 2016, s. 17). Czy jest to jednak zawsze skutek wychowania w rodzinie mieszanej, a może trzeba uwzględnić szersze konteksty postmodernistycznego nastawianie jednostki do religii? Należałoby także wrócić uwagę, iż mimo religijności selektywnej w świetle doniesień badani odczuwają silne związki z kulturą judaistyczną, wyrażając to poprzez pewne zaangażowanie kulturowe (np. noszenie koszulek z żydowskimi emblematami i gwiazdy Dawida, czytanie prasy i literatury żydowskiej, nadawanie żydowskich imion dzieciom, stawianie menory w oknie) (Bernstein, 2014, s. 19).

Posiadanie halachicznego pochodzenia gwarantuje łatwiejszy akces do żydowskiej wspólnoty. „Bycie Żydem” w tym wypadku to więź prymordialna, która może (ale nie musi) być rozwijana w toku życia. Z kolei korzenie od strony ojca oznaczają większe trudności, narażenie się na społeczne wykluczenie, mimo że osoby te deklarują nawet silniejsze zaangażowanie, a wręcz uznają siebie za bardziej wiernych tradycji w codziennym życiu (tamże, s. 28-30). Instytucjonalne zakorzenienie jest bardzo ważne dla wszystkich badanych, dlatego też nieposiadający halachicznego proweniencji szukają alternatywnych form identyfikacji w innych żydowskich instytucjach, spo- 
łecznościach, grupach studenckich. Osoby ukierunkowane na rozwój stricte religijny decydują się na konwersję. Co istotne, cała badana rosyjskojęzyczna grupa niemieckich Żydów uznaje wyłącznie konwersję ortodoksyjną. Wszyscy respondenci również mniej lub bardziej świadomie akceptują ideę biologicznego kryterium etnicznego, poprzez zinternalizowanie zasad matrylineażu (tamże, s. 7).

Nie-żydowscy dziadkowie i krewni nie zawsze są w stanie wyzbyć się uprzedzeń czy chęci dominacji w procesie socjalizacji kulturowej i religijnej (np. wymuszając chrzest, zaprowadzając dziecko do kościoła, obchodząc wspólnie chrześcijańskie święta). To rodzi pewne napięcia w rodzinie, również w małżeństwie dwureligijnym (tamże, s. 22).

Badani w różnych formach doświadczali antysemityzmu, głównie w szkole (jeszcze w byłym ZSRR), a już w Niemczech w postacie żartów bądź zaczepek. Nawet ich nie-żydowscy rodzice byli narażeni na dyskryminację. Wywołuje to u badanych dalsze dylematy tożsamościowe, zwłaszcza u osób pozbawionych halachicznego pochodzenia. Niestety - są na tyle Żydami, aby odczuć antysemityzm, a są zbyt mało „żydowscy”, aby zostać w pełni zaakceptowanym przez żydowskie instytucje (tamże, s. 8).

\section{Wnioski}

Raporty dostarczają interesujący materiał analityczny, otwierają czytelnika na codzienną wielokulturowość i dylematy identyfikacyjne dzieci z rodzin mieszanych. Ujawniają wspólne trendy w trzech badanych krajach:

- wszystkie raporty potwierdziły, że droga do asymilacji nie jest czymś nieuniknionym; dzieci z rodzin mieszanych nie zawsze tracą kontakt z judaizmem; często stanowi on immanentną część ich tożsamości. Dzieci wychowane w częściowo żydowskim domu, związane z żydowskimi instytucjami mogą rozwijać tożsamość żydowską; poszukują swoich korzeni i wykazują aktywną postawę w celu odnalezienia odpowiedniego dla siebie środowiska żydowskiego (Dimentstein, 2014, s. 5),

- duże znaczenie w kwestii socjalizacji i rozwoju tożsamości żydowskiej odgrywa halachiczne pochodzenie. Występuje tutaj podwójny problem: wykluczenie kulturowe dzieci z rodzin mieszanych oraz religijne (z uwagi na niehalachiczne pochodzenie dzieci posiadających żydowskiego ojca). To „pukanie do drzwi, które nie chcą się otworzyć” (Dawid, 2014, s. 10),

- poczucie odrzucenia u osób wychowanych w rodzinie mieszanej: 


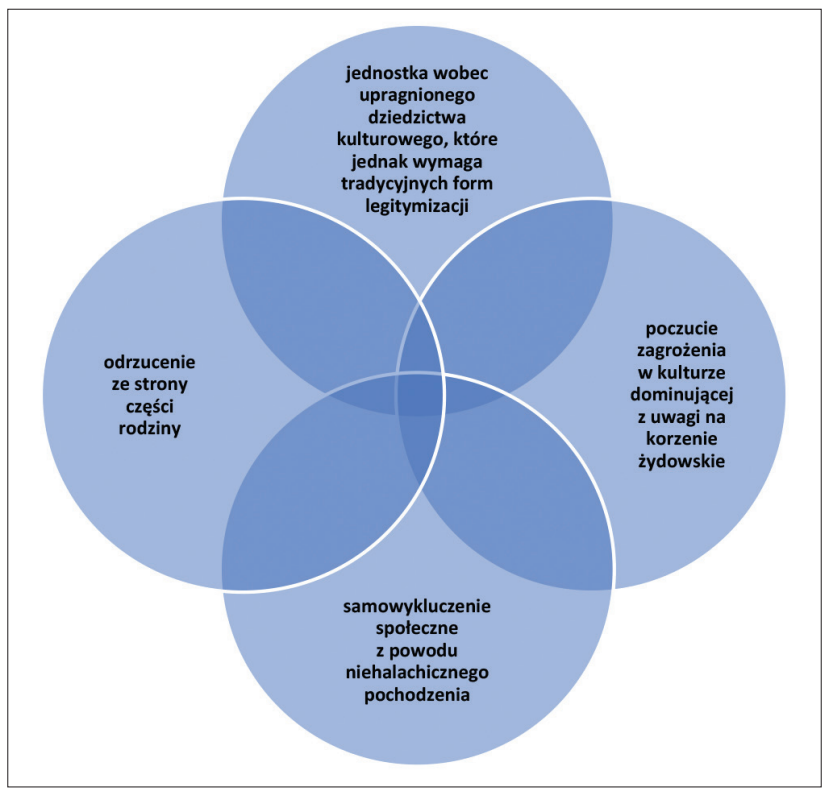

Źródło: opracowanie własne.

\section{które skutkować może:}

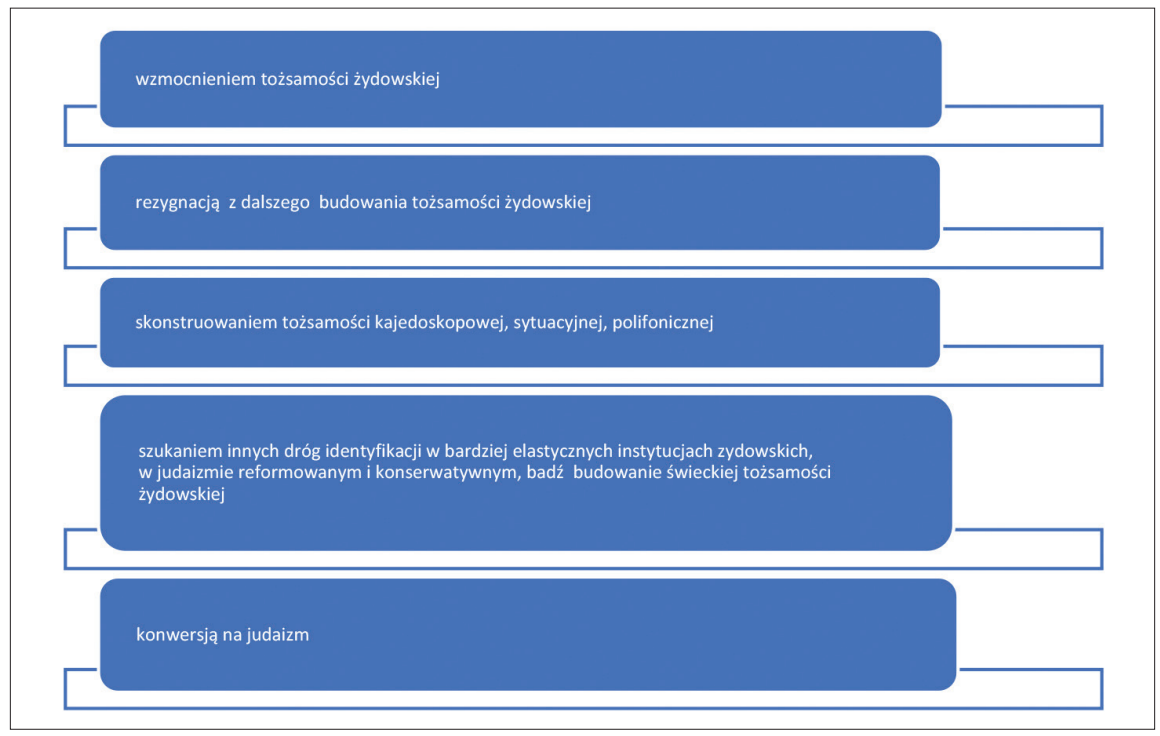

Źródło: opracowanie własne. 
- praktyki kulturowe (religijne) dzieci z małżeństw mieszanych są zróżnicowane. Badania ilościowe (na kształt brytyjskiego raportu JPR) zapewne dałyby pełniejszy obraz uczestnictwa w życiu wspólnotowym,

- identyfikacje etniczne są płynne, sytuacyjne, zindywidualizowane i bardzo skompilowane. Najczęściej nie jest rozwijana tożsamość stricte religijna,

- nie można jednoznacznie stwierdzić, że osoby mające korzenie ze strony ojca lub bardziej odległe są mniej zaangażowane w życie wspólnoty żydowskiej. W wielu wypadkach wiążę się bezpośrednio z poczuciem wykluczenia i stanowi jego konsekwencję. Nierzadko wykazują się dużą determinacją w budowaniu żydowskiej tożsamości,

- brak transmisji kulturowej lub minimalny przekaz dziedzictwa od starszego pokolenia (dziadkowie). Rodzice w roli uczący się „żydostwa” wraz z dziećmi. Zróżnicowane postawy rodziców nie-żydowskich oraz innych członków rodziny,

- raporty sugerują również, iż egzogamia jest powtarzana w kolejnych generacjach, bowiem także respondenci decydują się na tego typu związki,

- wielość czynników warunkujących budowanie żydowskiej tożsamości, należą do nich m.in.:

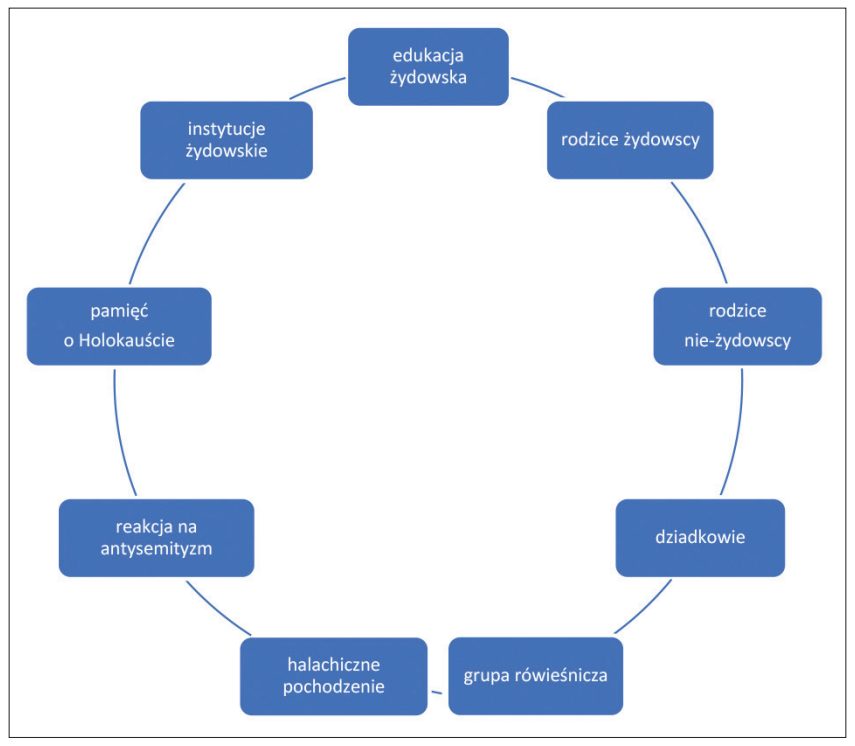

Źródło: opracowanie własne. 
Każdy z raportów kończy się wytycznymi dla polityki społecznej. Apelem o większą otwartość na nowych członków, szczególnie wobec mających korzenie ze strony ojca. Zwiększeniem pomocy skierowanej do najmłodszych dzieci, tak aby jako bardzo młode osoby miały okazję zakorzenić się w tradycji żydowskiej (Tanenbaum i Kooyman, 2014, s. 42). Jak przekonuje J. David, dzieci $\mathrm{z}$ rodzin mieszanych to wielka szansa na lepsze rozumienia istoty żydowskiego życia w szerszym społeczeństwie. W dorosłym życiu ich domy mogą być nawet bardziej żydowskie, z uwagi na ciągłą walkę o utrzymanie refleksyjnych związków z judaizmem (Dawid, 2014, s. 21). Stworzenie specjalnych, atrakcyjnych programów kulturowych dla rodzin mieszanych w Niemczech - zdaniem J. Bernstein (2014, s. 34) - jest czymś absolutnie koniecznym i pilnym.

Stosunkowo mało dowiadujemy się o samym procesie negocjowania tożsamości pomiędzy partnerami w rodzinie mieszanej. Nieocenioną pozycją dla zrozumienia tych procesów są książki Double or Nothing? Jewish families and mixed marriage, Sylvii Barack Fishman (2014) oraz Still Jewish: A History of Women and Intermarriage in America, Keren R. McGinity (2010) rzucające światło na codzienne praktyki, łączenie tradycji i próby wspólnego obchodzenia świąt w rodzinach dwukulturowych w Ameryce. Zaprezentowane badania europejskie skoncentrowały się na jednym elemencie dwukulturowości dzieci z rodzin mieszanych - a mianowicie sposobach konstruowania tożsamości żydowskiej oraz niełatwych relacji ze środowiskiem żydowskim. W tym ujęciu tożsamość dwukulturowa to przede wszystkim duże wyzwanie, obciążenie i bagaż dla jednostki.

Należy podkreślić, że nie zawsze Żydzi z rodzin mieszanych postrzegają siebie w takich kategoriach. Cząstka „żydowska” jest elementem dodatkowym, bardzo prywatnym, rozwijanym dopiero w dorosłym życiu. Poszukiwania identyfikacyjne młodych ludzi stanowią o specyfice europejskich małych diaspor, tzw. „trzeciej generacji Żydów po Holokauście” (Por. Reszke, 2013). W związku z tym, że są to społeczności znacznie mniejsze od diaspory amerykańskiej (szczególne w Holandii i Niemczech), znalezienie partnera żydowskiego może być po prostu trudne. Zdecydowanie inne są również konteksty historyczne i powody przerwania przekazu międzygeneracyjnego.

Z pewnością potrzebne są także odrębne raporty w Europie Środkowo-Wschodniej. Ponadto, zwróćmy uwagę, że zastosowany w badaniach przedział wiekowy 20-40 jest bardzo szeroki. Większość respondentów posiada już własne rodziny i należy podjąć starania o dalsze, bardziej szczegółowe badania nad preferowanymi przez nich modelami wychowawczymi i realiami życia rodzinnego tejże generacji. 


\section{Bibliografia}

A portrait of Jewish Americans, Findings from a Pew Research Center Survey of U.S. Jews, http://www.pewforum.org/2013/10/01/jewish-american-beliefs-attitudes-cultu re-survey/ (15.07.2017).

Alba, R. 2006. On the Sociological Significance of the American Jewish Experience: Boundary Blurring, Assimilation, and Pluralism, Sociology of Religion 67(4), pp. 347-358.

America's Changing Religious Landscape, Pew Research Center, http://www. pewforum. org/2015/05/12/chapter-2-religious-switching-and-intermarriage (15.07.2017).

Barack Fisman, S. 1994. The changing American Jewish Family Faces the 1990's. In: Bayme, S., Rosen, G. eds. The Jewish family and Jewish continuity. Nowy Jork: KTAV Publishing House, pp. 51-88.

Barack Fisman, S. 2004. Double or Nothing? Jewish families and mixed marriage. Waltham: Brandeis University Press.

Berman, L.A. 1968. Jews and Intermarriage: A Study in Personality and Culture. New York: T. Yoseloff Publisher.

Bernstein, J. 2014. „Once in a while kosher, once in a while Shabbat”. A Study on the Identities, Perceptions, and Practices of Children of Mixed Marriages in Germany, JDC International Centre for Community Development (JDC-ICCD), http://www.bjpa.org/Publications/details.cfm?PublicationID $=21927$ (05.07.2017).

Brodbar-Nemzer J.Y. 1988. The Contemporary American Jewish Family. In: Thomas, D.L. ed. The Religion and Family Connection: Social Science Perspectives, Provo: Brigham Young University, pp. 66-87.

Cohen, M.S., Ukeles, B.J., Miller, R. 2013. Jewish Community Study of New York: 2011 - Special Study on Partly Jewish Jews, http://www.bjpa.org/ Publications/details.cfm?PublicationID=18608 (15.06.2017).

Cukras-Stelągowska, J. 2016. Małżeństwa mieszane w społeczności żydowskiej - aberracja czy norma społeczna?, Wychowanie w Rodzinie 2 (XIV), ss. 317-339.

Dawid, J. 2014. „My Jewish part: Being a Part of Judaism or Keeping Judaism Apart?" The transmission of Judaism among children of mixed marriages residing in the Paris metropolitan area, JDC International Centre for Community Development (JDCICCD), http://www.bjpa.org/publications/ downloadFile.cfm?FileID = 21545 (4.07.2017). 
Dershowitz, A.M. 1997. The Vanishing American Jews: Search of Jewish Identity for the Next Century. Nowy Jork: Littel. Brown\&Company.

Dimentstein, M. 2014. Prologue. From Threat to Challenge? In: Dawid J.„My Jewish part: Being a Part of Judaism or Keeping Judaism Apart?” The transmission of Judaism among children of mixed marriages residing in the Paris metropolitan area, JDC International Centre for Community Development (JDCICCD, http://www.bjpa.org/publications/downloadFile. cfm?FileID = 21545 (04.07.2017).

Glenn, S.A., Sokoloff, N.B. 2010. Boundaries of Jewish Identity. Washington: University of Washington Press.

Goldscheider, C. 2004. Studying the Jewish future, Waszyngton: University of Washington Press.

Gordon, A. 2014. Jewish Intermarriage in American Society: Literature Review, Women in Judaism: A Multidisciplinary Journal, 2 (11), pp. 1-14.

Graham, D. 2016. Jews in couples: Marriage, intermarriage, cohabitation and divorce in Britain, Institute for Jewish Policy Research Report, http:// www.jpr.org.uk/publication?id=4582\#.V6ZxLP3r2Wk (5.08.2016).

Green, D. 2011. The Jewish Origins of Cultural Pluralism: The Menorah Association and American diversity. Bloomington: Indiana University Press.

Heilman, U. 2013. Pew survey of U.S. Jews: soaring intermarriage, assimilation rates, http://www.jta.org/2013/10/01/news-opinion/united-states/pew-surveyu-s-jewish-intermarriage-rate-rises-to-58-percent (16.06.2017).

Larkin, J. From generation to generation. A story of intermarriage. New York: CreateSpace Independent Publishing Platform.

Linzer N.: Self and Others: The Jewish family in crisis. In: Linzer, N. , Levitz, I. N., Schnall D. J. eds. Crisis and Continuity: The Jewish Family in the 21st Century. Nowy Jork: KTAV Publishing House, pp. 1-22.

McGinity, K.R. 2010. Still Jewish: A History of Women and Intermarriage in America. New York: New York Uniwersity Press.

Petsonk, J., Remsen, J. 2012. The Intermarriage Handbook: A Guide for Jews $\mathcal{E}$ Christians. New York: Quill Publisher.

Reszke. K. 2013. Powrót Żyda. Narracje tożsamościowe trzeciego pokolenia Żydów w Polsce po Holokauście. Kraków - Budapeszt: Wydawnictwo Austeria.

Sasson, T., Aronson, J.K., Chertok, F. 2015. Millennial Children of Intermarriage: Touchpoints and Trajectories of Jewish Engagement https://www. brandeis.edu/cmjs/pdfs/intermarriage/MillennialChildrenIntermarriage1. pdf (15.07.2017). 
Spickard, P.R. 1989. Mixed Blood: Intermarriage and Ethic Identity in Twentieth-century America. Madison: The University of Wisconsin Press.

Tanenbaum, B., Kooyman, R. 2014. Jewish feelings, Jewish practice? Children of Jewish intermarriage in the Netherlands, JDC International Centre for Community Development (JDC-ICCD), http://www.bjpa.org/Publications/details.cfm? PublicationID=21929 (5.07.2017).

Teutsch, D.A. ed. 1992. Imagining the Jewish future. Nowy Jork: State University New York Press.

Thompson, J.A. 2014. Jewish on Their Own Terms: How Intermarried Couples are Changing American. New Brunswick, New Yersey, London: Rutgers University Press.

\section{Cultural enrichment, confusion or exclusion? The consequences of upbringing in the mixed Jewish family in the context of European reports}

Abstract: I adopted the question of shaping the identity of children raised in mixed families as the subject of this article. In the light of three European reports, I would like to answer the question whether it constitutes cultural enrichment, confusion or exclusion for an individual. The German, Dutch and French reports show the consequences for adolescence in face of serious identification challenges faced by young people of Jewish descent. I attempt to make comparisons between the research results of three teams, looking for common features shared by these countries, also trying to identify the unique character of the studied cultural areas.

Keywords: mixed Jewish family, Jewish upbringing, identity

Translated by Joanna Cukras-Stelągowska 